\title{
JIPK
}

\section{JURNAL ILMIAH PERIKANAN DAN KELAUTAN}

\section{$\underline{\text { Research Article }}$}

\section{Budidaya Seabass Asia (Lates calcarifer) di Keramba Jaring Apung di Pusat Pengembangan Budidaya Perairan Air Payau}

\section{The Culture of Asian Seabass (Lates calcarifer) in Floating Net Cages at the Brackishwater Aquaculture Development Center}

\section{Fadhliyatud Diniyyah ${ }^{1 *}$}

${ }^{1}$ School of Fisheries and Aquaculture Sciences, Universiti Malaysia Terengganu, Malaysia, Kuala Terengganu 21030

\section{ARTICLE INFO \\ Received: September 20, 2018 \\ Accepted: November 20, 2018 \\ *) Corresponding author: \\ E-mail: diniyyah95@gmail.com}

\section{Kata Kunci:}

Kakap putih Asia, Lates calcarifer, Budidaya, Keramba jaring ikan, Pakan ikan

Keywords:

Asian seabass, Lates calcarifer, Culture, Floating net cages, Fish feed

\begin{abstract}
Abstrak
Studi ini bertujuan untuk mengetahui pengaruh budidaya kakap putih Asia (Lates calcarifer) di keramba jarring apung di pusat pengembangan budidaya air payau, Situbondo. Kakap putih Asia diberi pelet ikan komersial (KPA) dengan ikan segar (limbah ikan) selama 21 hari. Kakap putih makan dengan limbah ikan dan pelet ikan komersial menunjukkan respon pertumbuhan rata-rata dari berat dan panjang. Pertumbuhan ikan dari berat awal 230g, 238g dan 244g pada hari ke21 dan terjadi perubahan panjang rata-rata kakap putih masing-masing menjadi $23 \mathrm{~cm}, 25 \mathrm{~cm}$ dan $28 \mathrm{~cm}$. Ikan diberi makan dengan 3-7\% dari berat badan ikan dan pertumbuhan diamati dalam 21 hari. Hasil penelitian menunjukkan bahwa limbah ikan dapat meningkatkan respon pertumbuhan yang signifikan di kakap putih Asia.
\end{abstract}

\begin{abstract}
This study aim was carried out to investigate the effect of Asian seabass (Lates calcarifer) culture in floating net cages at the Brackishwater Aquaculture Development Center, Situbondo. Asian seabass were fed with commercial fish pellet (KPA) and fresh fish (trash fish) for 21 days. Seabass fed with trash fish and commercial fish pellet displayed the growth response to the average weight and length. The fish grew from an initial weight of $230 \mathrm{~g}, 238 \mathrm{~g}$, and $244 \mathrm{~g}$ in 21 days and the average length of seabass changed from $23 \mathrm{~cm}, 25 \mathrm{~cm}$ and $28 \mathrm{~cm}$ respectively. The fish were fed with $3-7 \%$ body weight of fish and the growth was monitored in 21 days. The results showed that trash fish can increase the significant growth response in Asian seabass.
\end{abstract}

Cite this as: Fadhliyatud, D. (2018). Budidaya Seabass Asia (Lates calcarifer) di Keramba Jaring Apung di Pusat Pengembangan Budidaya Perairan Air Payau. Jurnal Ilmiah Perikanan dan Kelautan, 10(2):65-69. http://doi.org/10.20473/jipk.v10i2.10364 


\section{Introduction}

Lates calcarifer or Asian seabass is commonly known as 'Kakap Putih' in Indonesia. Asian seabass belongs to the Centropomidae family like other seabass and this seabass is one of the economically important food fish in tropical and sub-tropical regions of the Indo-Pacific (Wilson, 1991). It also serves as a sports fishing commodity, especially in Australia followed by the Indian Ocean countries, including India, Burma, Sri Lanka, Malaysia, Indonesia, and Taiwan. Seabass is classified as a bottom-living fish that live in seawater and this species is catadromous that can grow in freshwater and breed in the marine environment.

The advantages of Asian seabass culture is that they have considerable toleration to salinity or

\section{Materials and Methods}

The industrial training activities were carried out starting on August $13^{\text {th }}$ to September $12^{\text {th }} 2018$. Asian seabass Lates calcarifer was cultured in floating net cages at the Brackish water Aquaculture Development Center, Pecaron Hamlet, Klatakan Village, Kendit District, Situbondo Regency, East Java or Jl. Raya Pecaron PO. Box 5 Panarukan, Situbondo, East Java.

The growth of Asian seabass was monitored in culture net for 21 days. The fish was fed with commercial fish pellet and trash fish for their feed growth response. The average length and weight of seabass were measured and recorded for the growth data of fish and the average of fish samples taken was 10 fishes. Materials used in the culture of Lates

Table 1. Materials used in Lates calcarifer culture

\begin{tabular}{lll}
\hline No. & Name & Function \\
\hline 1 & Net & To culture Asian seabass \\
2 & Scoop net & To take seabass \\
3 & Basket & Place for freshwater and fish \\
4 & Scissor & To cut trash fish \\
5 & Weight balance & To weigh fish \\
6 & Pumping machine & To clean the net \\
7 & Thermometer & To measure the water temperature \\
8 & Ruler & To measure the length of the fish \\
9 & Bottle & To take water samples \\
10 & Life jacket & For safety \\
11 & Motorboat & As transportation to KJA \\
12 & Sinker & As sinker to net \\
13 & pH meter & To measure pH value \\
14 & DO meter & To measure dissolved oxygen \\
15 & Refractometer & To measure water salinity \\
16 & Plastic drum & For soaking the fish \\
17 & Pipe & For spraying water to clean net cages \\
18 & Camera & Take photos for documentation \\
\hline
\end{tabular}

euryhaline and faster growth rate (Rao et al., 2013). Seabass can be identified by its body shape type with anelongated and compressed body as well as a pointed head. The scale is ctenoid and large and the color is greenish silver similar to the body of the fish. The species has a very interesting ecological distribution at its various stages of life. The fish spend most of its life in a lagoon which connects to sea water. it spent two to three more years in estuary areas to mature and then migrate to the sea around the river mouth or lagoon for spawning. Larvae and juveniles of Asian seabass live in coastal areas for six months and grow to a size of 2 to 5 inches calcarifer are shown in Table 1.

\section{Results and Discussion}

In this study, the Asian seabass was fed with commercial fish pellet and trash fish for 21 days. The feed was given at $3-7 \%$ of the fish body weight. Asian seabass showed the increase in total length and total weight for each week. The average weight and length were shown in Table 2. The graph chart of average length and weight of Asian seabass was shown in Figures 1 and 2 . 


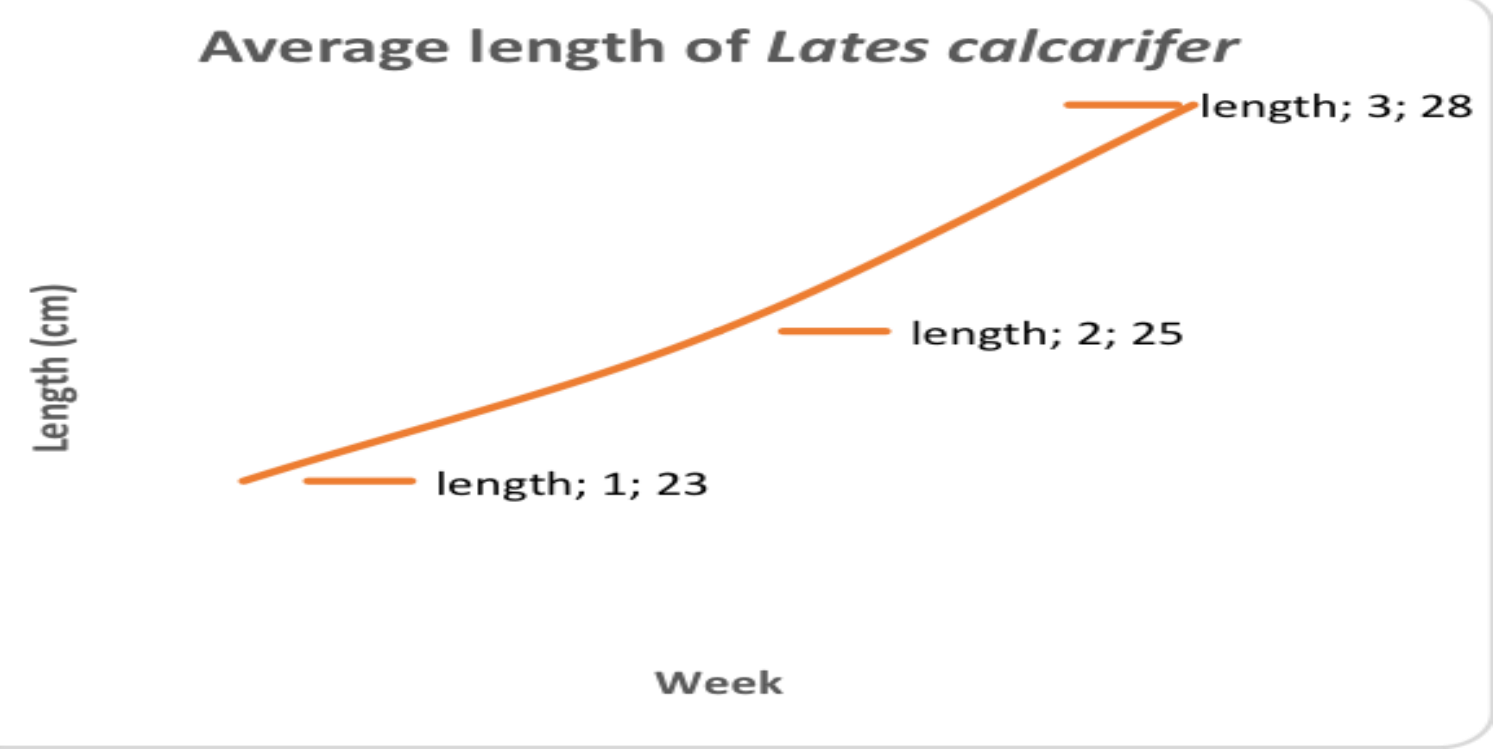

Figure 1. The average length of 10 Lates calcarifer observed for 21 days

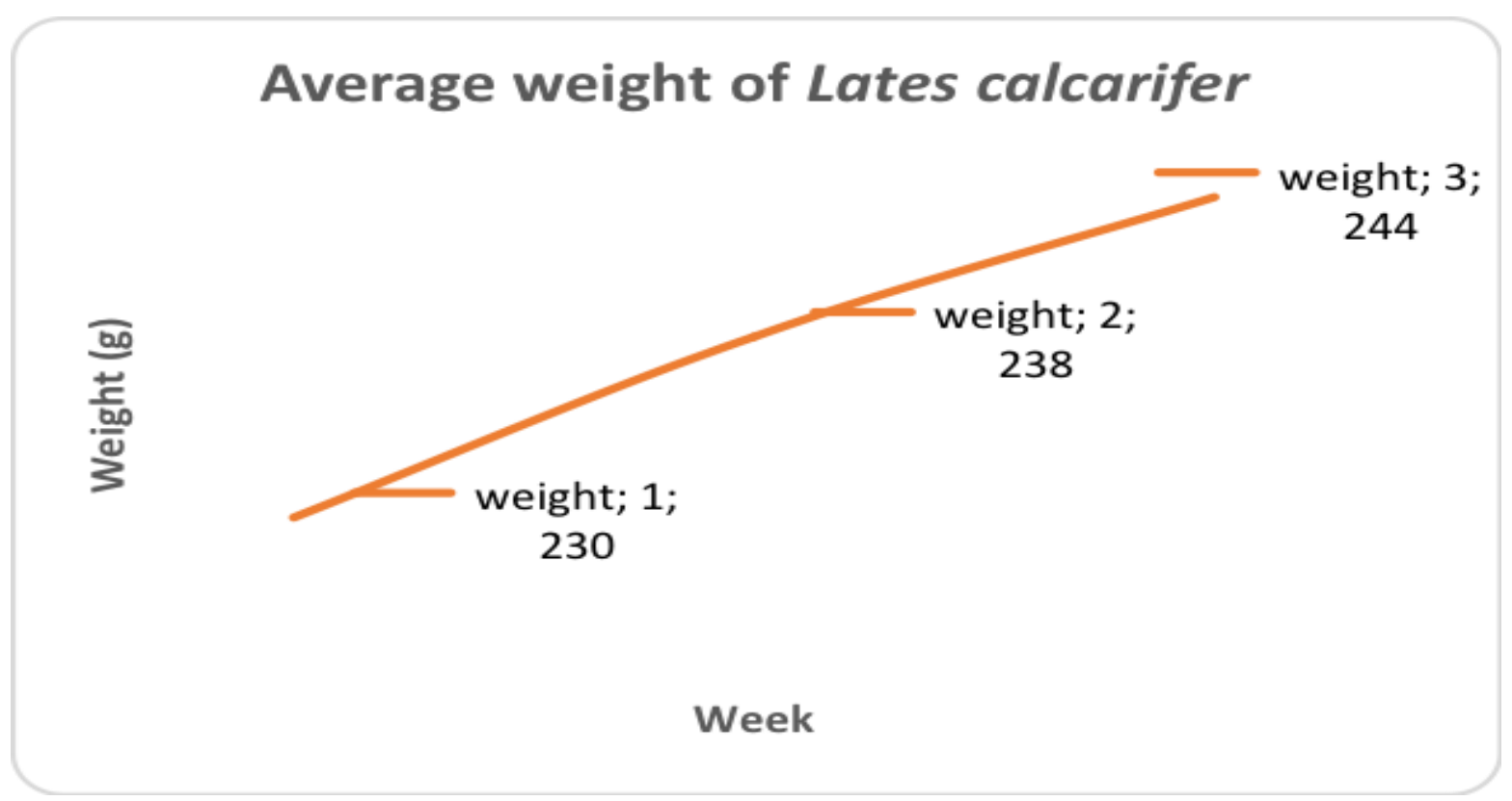

Figure 2. The average weight of Lates calcarifer observed for 21 days

There are two terms that are closely linked which are the growth and the stocking density of fish (Coulibaly et al., 2007). The growth rate of fish can be calculated using the final average weight of fish deducted with the initial average weight of fish and it also applies to the calculation of the average length of fish. The weight of seabass increased by 0.67 gram/day and the length of seabass grew by $0.24 \mathrm{~cm} /$ day. Hence, the result showed that the growth condition of Asian seabass in floating net cages in BADC Situbondo is slowly increasing in the growth culture. The fish feed was the main important for the growth performance of fish. It was supported by Nour et al. (1993) who stated that by increasing the fish feeding rates the growth performance in mullet fingerlings will also increase. According to Chua and Teng (1982), the best average weight, relatively good survival rates and better feeding efficiency is dependent on the feed given to fish 
Table 2: The average weight and length of seabass growth parameter for 21 days

\begin{tabular}{lccc}
\hline Growth Parameter & Week 1 & $\begin{array}{c}\text { Time } \\
\text { Week 2 }\end{array}$ & Week 3 \\
\hline Average Weight $(\mathrm{g})$ & 230 & 238 & 244 \\
Average Length $(\mathrm{cm})$ & 23 & 25 & 28 \\
\hline
\end{tabular}

Table 3: The average results of water quality parameter for 21 days

\begin{tabular}{ll}
\hline Water Parameter & $\begin{array}{l}\text { Test result } \\
\text { Average }\end{array}$ \\
\hline Temperature $\left({ }^{\circ} \mathrm{C}\right)$ & $26.5-28.0$ \\
Dissolved oxygen $(\mathrm{DO})$ & 6.0 \\
$\mathrm{pH}$ & $7.5-8.38$ \\
Water transparency $(\mathrm{m})$ & 15.5 \\
Salinity $(\mathrm{ppt})$ & 33.0 \\
Ammonia $(\mathrm{mg} / \mathrm{L})$ & $<0.001$ \\
Nitrite $(\mathrm{mg} / \mathrm{L})$ & $<0.001$ \\
\hline
\end{tabular}

Water quality parameters were checked twice weekly. The average water temperature was around 26.0 to $28.0{ }^{\circ} \mathrm{C}$ and the average $\mathrm{pH}$ value was around 7.5 to 8.4 . Nitrite $\left(\mathrm{NO}_{2}\right)$, and ammonia were lowest at $<0.001 \mathrm{mg} / \mathrm{L}$ and the dissolved oxygen was $6.0 \mathrm{mg} / \mathrm{L}$. The water quality parameter is shown in Table 3.

\section{Conclusion}

In conclusion, this study showed that there are increased weight and length of Asian seabass in floating net cages when fed with trash fish and commercial fish pellet. The average fish weight is $230 \mathrm{~g}, 238 \mathrm{~g}$ and $244 \mathrm{~g}$ and the average fish length is $23 \mathrm{~cm}, 25 \mathrm{~cm}$, and $28 \mathrm{~cm}$ for 21 days respectively.

\section{Acknowledgment}

Special thanks to the Brackish water Aquaculture Development Center (BADC) for allowing me to conduct my industrial training activities there for 21 days to culture Asian seabass (Lates calcarifer) in floating net cages and monitoring the fish growth.

\section{References}

Chua, T. E., \& Teng, S. K. (1982). Effects of food ration on growth, condition factor, food conversion efficiency and net yield in floating net cages. Aquaculture, 27: 273-283.

Coulibaly, A., Ouattara, I. N., Kone, T., N'Douba, V., Snoeks, J., Bi, G. G., \& Kouamelan, E. P. (2007). First results of floating cage culture of the African catfish Heterobranchus longifilis Valenciennes, 1840: Effect of stocking density on survival and growth rates. Aquaculture, 263: 61-67.

Luna, S. (2008). Lates calcarifer, Barramundi: fisheries, aquaculture, gamefish, aquarium: [online]. Fish base, Accessed April 02, 2008 http://fishbase.sinica.edu.tw/summary/species summary.php?

Rao, G. S., Joseph, I., Philipose, K. K., \& Mojjada, S. K. (2013). Cage aquaculture in India. Central Marine Fisheries Research Institute Kochi, 233 pp.

Tacon, A. G. J., Rausin, N., Kadari, M. \& Cornelis, P. (1991). The food and feeding of tropical 
JIPK. Volume 10 No 2. November 2018 / Budidaya Seabass Asia (Lates calcarifer) di Keramba Jaring Apung.......

marine fishes in floating net cages: Asian seabass, Lates calcarifer (Bloch) and brownspotted grouper, Epinephelus tauvina (Forskal). Aquaculture Research, 22(2): 165-182.

Wilson, R. P. (1991). Handbook of Nutrient requirements of Finfish. CRC Press Book. Australia 